\title{
Do environmental variables predict the trophic structure of fish fauna in a subtropical river (Uruguay River Ecoregion)?
}

\author{
Mayara P. NEVES,${ }^{1 *}$ Dirceu BAUMGARTNER,${ }^{2}$ Gilmar BAUMGARTNER,${ }^{2}$ Rosilene L. DELARIVA ${ }^{3}$ \\ ${ }^{1}$ Departamento de Zoologia, Programa de Pós-Graduação em Biologia Animal, Universidade Federal do Rio Grande do Sul, Avenida \\ Bento Gonçalves 9500, Agronomia, Prédio 43435, Sala 111, Porto Alegre, 91501-970 Rio Grande do Sul; ${ }^{2}$ Centro de Engenharias e \\ Ciências Exatas, Grupo de Pesquisas em Recursos Pesqueiros e Limnologia, Universidade Estadual do Oeste do Paraná, Rua da Faculdade \\ 645, Jardim La Salle, 85903-000 Toledo; ${ }^{3}$ Centro de Ciências Biológicas e da Saúde, Universidade Estadual do Oeste do Paraná, Programa \\ de Pós-Graduação em Conservação e Manejo de Recursos Naturais, Rua Universitária 2069, 85819-110 Cascavel, Brazil \\ *Corresponding author: mayara-nevesbio@hotmail.com
}

\begin{abstract}
Trophic interactions represent the routes through which energy flows upwards within ecosystems and the understanding of such structuring under varying environmental conditions is still challenging. Here we test the hypothesis that differences in environmental variables act as environmental filters on the composition and trophic structure of local the fish fauna of a subtropical mountain river. We predict that differences in the trophic structure of the fish fauna occur along the river continuum. Main environmental parameters have been measured and fishes were sampled quarterly between August 2013 and May 2014 at six sampling sites in the main channel of the Pelotas River, Upper Uruguay ecoregion. We collected 3848 individuals belonging to 38 species, 4 orders and 11 families. The most $(82.1 \%)$ consisted of small- and medium-sized individuals. The species were classified into eight trophic guilds: aquatic insectivorous, carnivorous, detritivorous, detritivorous/aquatic insectivorous, herbivorous, iliophagous, omnivorous and piscivorous. In general, herbivorous and piscivorous guilds were the most representative in both number and biomass. Significant differences detected by Permanova were for richness, numerical abundance and biomass between all the sites sampled. Relationships between the environmental variables and the composition of trophic guilds were observed along the longitudinal gradient by RLQ and fourth-corner analyses. The abundance of guilds omnivorous, aquatic insectivorous and herbivorous increases with higher values of chlorophyll- $a$ and vegetation cover, especially characterizing the upstream sites (S1, $\mathrm{S} 2$ and S3). On the other hand, the abundance of the iliophagous, detritivorous/insectivorous and piscivorous guilds increases with greater values of width, temperature, inorganic phosphorus and total solids, a fact observed in downstream sites (S4, S5 and S6). Thus, it was possible to identify a clear variation in the trophic structure of the fish fauna along the Pelotas River (upstreamdownstream), in which the local variables were efficient in predicting environmental filters that influence the trophic organization. In this scenario, our study follows the longitudinal model and evidences a greater accumulation of energy in food webs in the upstream-downstream direction, which favors the greatest abundance of piscivorous, detritivorous and iliophagous verified in stretches of greater volume and dimensions of river. These results highlight the importance of the local variables and the interrelationships in the lateral connectivity processes along the river continuum.
\end{abstract}

Key words: Freshwater; lotic; trophic guilds; environmental filters; longitudinal gradient.

Received: December 2017. Accepted: March 2017.

\section{INTRODUCTION}

The understanding of ecosystem processes, especially environmental predictors in river systems, is a challenging ecological issue. Since the inception of the river continuum concept (RCC) (Vannote et al., 1980) and the serial discontinuity concept (SDC) (Ward and Stanford, 1983), the environmental gradient assumptions in rivers were very strongly focused on longitudinal functions and processes. Thus, theoretical constructs, such as biotic and abiotic interactions on trophic structure and energy sources in ecosystems have been the attention of many studies in lotic environments (Carvalho and TejerinaGarro, 2015; Leitão et al., 2017; Röpke et al., 2017). The longitudinal distribution of aquatic organisms along a gradient of environmental conditions is a basic premise of the River Continuum Concept. Additional refinements and developments, with the inclusion of other variables, were discussed by Stanford and Ward (2001). In this regard, biological communities can adjust to environmental changes through species substitution as well as different forms of energy use.

Trophic interactions represent the routes through which energy flows upwards within the structure of ecosystems (Saint-Béat et al., 2015). However, the understanding of this structuring under natural environmental conditions is still a challenge, which becomes even more promising, given the increasing 
effects caused by anthropic impacts, such as deforestation and impoundments (Delariva et al., 2013; Félix et al., 2013; Furlan et al., 2013; Schork et al., 2013; Franchi et al., 2014; Gandini et al., 2014; Zeni and Casatti, 2014). In this sense, the use of trophic guilds is widely used in literature as a convenient method to summarize feeding habits data for a large group of species; i.e., nontaxonomic groups of species which exploit the same resource(s) (Gerking, 1994). This approach has been very useful in understanding the various trophic interactions exhibited by fish (Hargreaves et al., 2017) as well as the functional trait selection (Mouillot et al., 2013; Troia and Gido, 2015; Winemiller et al., 2015; Fitzgerald et al., 2017). Thus, trait-based approaches that focus on groups of co-occurring species with shared ecological traits, such as fish trophic guilds, may reveal a unique response of the fish community to environmental gradient (Macnaughton et al., 2016) as well as anthropic disturbance.

Along the gradient of fluvial systems, a number of factors can drive and affect fish community structure, including geographic position and geomorphological history (Ibanez et al., 2007; Esteves et al., 2008; Félix et al., 2013; Caravalho and Tejerina-Garro, 2015). In addition to these, alterations in the trophic guild composition pattern are attributed to environmental filters (Córdova-Tapia et al., 2017), mainly those related to differences in water quality, energy input into the system (Vannote et al., 1980) as well as the availability and supply of food (Bonato et al., 2012; Wolff et al., 2013). In this scenario, evolutionary characteristics of the fish fauna are selected, based on the environmental constraints, as well as the exploitation ability and adaptability in resource partitioning. These processes lead to the establishment of typical functional trophic groups in environmental gradients (Connel, 1980; Carvalho and Tejerina-Garro, 2015; Fitzgerald et al., 2017).

In Neotropical region, the hydroeletric sector and construction of cascades of small hydropawer plants have been promote drastic changes on plateau rivers and rivers of high-priority for conservation (Affonso et al., 2015; Kliemann and Delariva, 2015; Latini and Pedlowski, 2016). Specifically, in Brazil's subtropical region, there are a limited number of studies on the trophic guilds of river fish. In addition, most of these studies have been focused in rivers that were already altered by dams (Mérona et al., 2001; Loureiro-Crippa and Hahn, 2006; Luz-Agostinho et al., 2006; Delariva et al., 2013). In neotropical environments already studied, such as streams, their trophic status is largely dependent on allochthonous energy sources (Peres-Neto et al., 1995; Wolf et al., 2013; Nimet et al., 2015). In floodplain systems, which are much more influenced by flood pulses, lateral connectivity promotes nutrient and energy exchange (Goulding et al., 1988; Lowe-McConnell, 1999;
Esteves et al., 2008, Leitão et al., 2017; Röpke et al., 2017). In plateau and embedded rivers although some of the above-mentioned premises are expected, local environmental heterogeneity, such as stretches with higher flow, rapids and differences in the marginal area/river width ratio can add important sources of differentiation along the longitudinal gradient. Moreover, the higher light incidence in the downstream reaches increases the autochthonous processes of energy upward flow (Melles et al., 2012). Rivers with these characteristics are good models for testing perspectives in relation to trophic structuring as a key element of the spatial/temporal fluvial dynamics.

The Pelotas River is classified as a mountain river (Uieda and Castro, 1999), with high slope and a range varying from 1600 to $160 \mathrm{~m}$. By presenting such characteristics, this river has a high potential for hydropower generation, which has driven numerous projects for the implementation of power plants (Ministério do Meio Ambiente, Secretaria de Recursos Hídricos, 2006). In addition, the presence of endemic species and the lack of knowledge about the biology of the fish fauna in the region highlight the importance of this type of research. In this sense, the hypothesis tested here was that differences in local environmental variables act as environmental filters on the composition and trophic structure of local fish fauna. In this respect, it is predicted that differences in the trophic structure of the fish fauna occur along the river continuum. Thus, the goals of this study were: i) to identify the trophic guilds along the longitudinal gradient of the Pelotas River; ii) to test for possible differences in richness and abundance, in number and in biomass, of the trophic guilds among sampling sites and seasons; iii) to correlate the environmental variables with the composition of trophic guilds along the river continuum. It is expected a greater abundance of herbivorous and omnivorous guilds related to upstream stretches, while piscivorous, detritivorous and iliophagous guilds are more related to the downstream sites, associated with a gradual increase of autochthonous source of energy. In addition, it is also expected that trophic structuring is related to local environmental heterogeneity and lateral dynamics, which may provide different resources along the longitudinal gradient.

\section{METHODS}

\section{Study area}

The Upper Uruguay ecoregion encompasses the drainage basins of the Uruguay River upstream of Yucumã Falls. This region includes the Uruguay River and all of its tributaries, including the two forming rivers, the Canoas and the Pelotas. The Pelotas River arises in 
the Serra Geral $64 \mathrm{~km}$ from the Atlantic Ocean and its basin is approximately $35,813 \mathrm{~km}^{2}$. It flows inland until it meets the Canoas River, where it forms the main stem of the Uruguay. The Upper Uruguay flows over steep and rocky terrain marked by rapids and falls. High turbidity, low nutrients, and high flow contribute to low phytoplankton productivity along the Uruguay. Similarly, variable water levels, rapid flow, steep banks, and rocky substrates limit permanent aquatic vegetation along the main stem. The Upper Uruguay lacks a well-defined dry season since rainfall occurs throughout the year. Flooding tends to be brief, with waters flowing quickly through deep valleys with no marginal lakes or floodplains to absorb rising waters (Zaniboni-Filho and Schulz, 2003; Abell et al., 2008).

In summer, rainfall distribution is uneven and evapotranspiration is high. The most pronounced debs occur in the fall and the weaker flows are found in March and April, with significant amplitudes between the maximum and the minimum, and an average flow of $258 \mathrm{~m}^{3} / \mathrm{s}$. The vegetation of the region is composed of meadow areas that usually occur at altitudes above 800 meters and Mixed Ombrophilous Forest, which occupies almost half of the basin and has two formations: Mountain Forest (altitudes between 500 and 1000 meters) and High Mountain (above 1000 meters altitude) (Strassburger, 2005).

\section{Sampling sections}

Samples were taken quarterly (seasonally) between August 2013 and May 2014 at six sampling sites in the main channel of the Pelotas River (Fig. 1).

\section{Environmental variables}

At each sampling site, the main environmental variables were measured: water temperature, $\mathrm{pH}$, conductivity, alkalinity, turbidity, transparency, color, total suspended matter, dissolved solids, dissolved oxygen, biochemical oxygen demand and chemical oxygen demand, chlorophyll- $a$, nutrients (total, inorganic and organic phosphorus; total, organic and ammonia nitrogen, nitrate, nitrite) and physical variables (width, flow and vegetation cover) (Supplementary Tab. 1).

\section{Biotic data}

Fish were collected under the license of the Instituto Brasileiro do Meio Ambiente e dos Recursos Naturais Renováveis (IBAMA) (Process IBAMA 1372, 1373, 1374 and 1376/2012). We used monofyllament gill nets $(2.5 ; 3$; $4 ; 5 ; 6 ; 7$ and $8 \mathrm{~cm}$ between non-adjacent knots) and trammel nets $(6 ; 7$ and $8 \mathrm{~cm}$ between non-adjacent knots) with $20 \mathrm{~m}$ in length and with height ranging from 1.44 to 1.80 meters according to the mesh, set out at $16: 00 \mathrm{~h}$ and inspected at 22:00 $\mathrm{h}$ and 8:00 h, remained exposed for $16 \mathrm{~h}$.
After caught, fish were fixed in $10 \%$ formaldehyde and preserved in $70 \%$ alcohol.

\section{Laboratory procedures and trophic categorization}

Specimens were identified in the laboratory according to Serra et al. (2014) and in case of doubts, individuals were sent to experts for confirmation (specific case of Hypostomus luteus (Godoy, 1980), Crenicichla celidochilus Casciotta (1987) and Astyanax cf. procerus Lucena, Castro and Bertaco, 2013). Each specimen was measured (total and standard length in $\mathrm{cm}$ ) and weighed (g), gutted and stomach were removed. According to size, species were classified as: small $(<20 \mathrm{~cm})$; medium (between 20 and $40 \mathrm{~cm}$ ) or large $(>40 \mathrm{~cm}$ ) (sensu Baumgartner et al., 2012). Voucher specimens were deposited in the fish collection of GERPEL (Grupo de Pesquisas em Recursos Pesqueiros e Limnologia), of the State University of Western Paraná and in the fish collection of Nupelia (Núcleo de Pesquisas em Limnologia, Ictiologia e Aquicultura) of the State University of Maringá.

For specimens with full stomach (fullness equal to or greater than $30 \%$ ) stomach contents were identified under optical and stereoscopic microscopes to the lowest taxonomic level possible. Food items were identified using the identification keys of Bicudo and Bicudo (1970) for algae and Mugnai et al. (2010) for invertebrates, and quantified according to the volumetric method; i.e., the total volume of a food item taken by the fish population is given as a percentage of the total volume of all stomach contents (Hyslop, 1980), using graduated test tubes and a glass counting plate (Hellawell and Abel, 1971).

\section{Data analysis}

In this study, through the analysis of 853 stomachs, it was possible to make the trophic categorization of the 13 most abundant species $(76.5 \%$ of the total numerical abundance). For most of these species, mainly Astyanax and Bryconamericus, besides being endemic to the region, there is no information in the literature about their biological aspects (Bonato et al., 2018). For the other species (26), due to the low sample size, we used bibliographic information regarding each one (or, when unavailable, for the genus). Most of these species are considered trophic specialists (eight detritivorous species: Hypostomus and Rineloricaria; six piscivorous: Crenicichla and Hoplias). Thus, the determination of the trophic guilds for these species through the literature does not induce doubtful interpretations, since their morphological characteristics do not allow trophic guild change as a function of spatial variations in their diet. In addition, we were careful to select information about their diets in the study region (Uruguay basin). 
For the determination of trophic guilds from the stomach contents matrix and bibliographic data, we adopted the criteria used by Mérona et al. (2001): more than $50 \%$ detritus/sediment in the stomachs: detritivorous; more than $50 \%$ aquatic insects in the stomachs: aquatic insectivorous; similar proportions of detritus and aquatic insects: detritivorous/insectivorous; more than 50\% various invertebrates in the stomachs: carnivorous; more than $50 \%$ fish in the stomachs: piscivorous; similar proportions of detritus and algae: iliophagous, more than
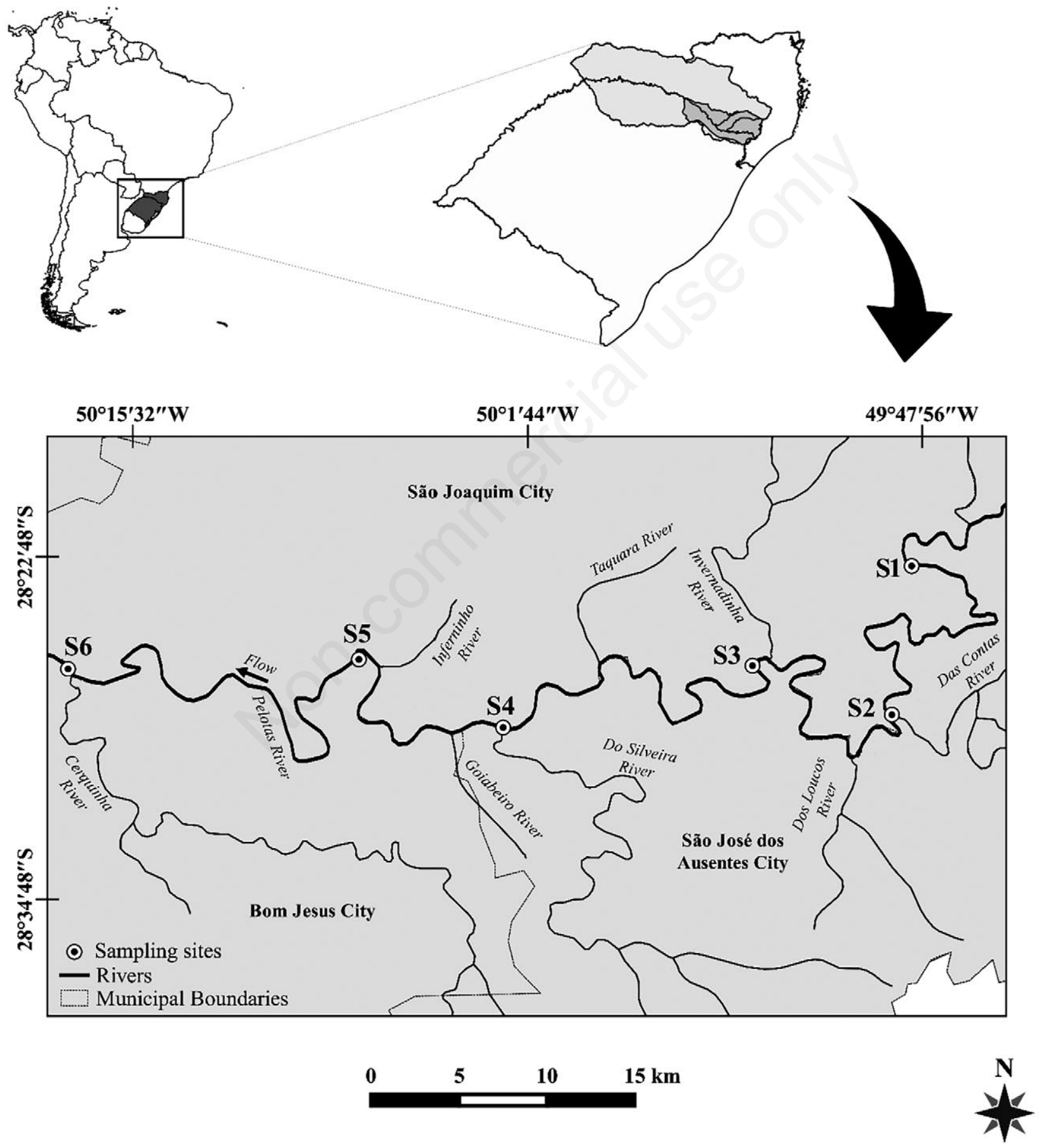

Fig. 1. Study area. Location of sampling sites in the Pelotas River (S1-S6), in Upper Uruguay ecoregion. 
$50 \%$ leaves/seeds in the stomachs: herbivorous; none of the above statements valid, and adding items from different origins (plant and animal): omnivorous. Finally, in our study, based on stomachs contents and on literature data, species were categorized into eight trophic guilds: aquatic insectivorous, carnivorous, detritivorous, detritivorous/aquatic insectivorous, herbivorous, iliophagous, omnivorous and piscivorous.

The trophic structure was evaluated considering species richness, abundance in number and biomass per trophic guild, and was indexed by catch per unit effort (CPUE, number of individuals in $1000 \mathrm{~m}^{2}$ of net within $16 \mathrm{~h}$ ) based on gill nets and trammel nets.

In order to test possible differences in the proportions of the trophic guilds (richness, numerical abundance and biomass), a two-way (sites and seasons) Permutation Multivariate Analysis of Variance (PERMANOVA) was run using the Bray-Curtis index obtained with 9999 permutations (Anderson, 2001).

In order to evaluate the relationship between the environmental variables and the trophic guilds, the RLQ analysis (Dolédec et al., 1996) was applied to detect trait responses to environmental gradient along the Pelotas River. RLQ is a multivariate technique, derived from coinertia, which allows relating of two or more matrices (Borcard et al., 2011; Dunck et al. 2016; Santos et al. 2017). The RLQ results in scores for the samples, considering the relationship between trophic guilds and environmental variables along orthogonal axes. In the present study, the matrices used were: $\mathrm{R}(n \times m)$, in which $n$ is the sampling sites and $m$, the local environmental variables; $\mathrm{L}(n \times s)$, where $n$ is the sampling sites and $s$, the species; in which the samples correspond to the relative abundance (CPUE) of the species collected at each sampling site; $\mathrm{Q}(s \times p)$, in which $s$ is the species and $p$, the trophic guilds $(0$ : absence of the trait, 1 : presence of the trait). We used permutation tests by the fourth-corner approach (Dray and Legendre, 2008) to test the relationship significance. Before carrying out RLQ analysis, due to the large number of environmental variables and possible correlations between them, we applied the Spearman correlation $(\rho)$ between pairs of these variables to exclude one of the most correlated $(\rho>0.50)$.

In each matrix, an independent ordination was performed according to the nature of the data. The matrix $\mathrm{L}$ was transformed into square root to reduce the influence of the dominant species in the analysis of community structure (Sokal and Rohlf 1995) and subjected to a correspondence analysis (CA) (Legendre and Legendre, 2012), the R matrix was log-transformed and subjected to Hill-Smith analysis (Hill and Smith, 1976) and the matrix Q was analyzed by a Principal Component Analysis (PCA). The final result of RLQ is a linear combination of environmental variables (matrix R) and functional trait (matrix Q) that maximizes covariance between these groups of variables, mediated by species abundance (matrix L).

All the analyses were performed in $\mathrm{R}$ environment version (R Core Team, 2015). For PERMANOVA, the 'vegan' package version 2.4-6 was used (Oksanen et al., 2007) while for RLQ, the 'ade4' package version 1.7-10 (Dray and Dufour, 2007). Also, 'dudi.coa' was used to execute the CA with the matrix L, the 'dudi.hillsmith' to perform the Hill-Smith analysis with the matrix R and the PCA for the matrix Q.

\section{RESULTS}

\section{Environmental variables}

From the environmental variables, it was possible to observe that with the decrease in altitude in the upstreamdownstream direction there was an increase in the channel width, reduction in flow and vegetation cover (Tab. 1). In relation to the water characteristics, the highest values of temperature and turbidity were found in the downstream sites (S4, S5 and S6). On the other hand, higher chlorophyll- $a$ concentrations were observed at the upstream site (S1) (Tab. 1).

\section{Trophic structure of the assemblage}

We collected 3848 individuals belonging to 38 species, 4 orders and 11 families, of which the majority consisted of small- (46.2\%) and medium-sized (35.9\%) individuals. The most numerically abundant species were Astyanax xiru Lucena, Castro and Bertaco, 2013 (23.2\%), Bryconamericus patriciae da Silva, 2004 (20.7\%) and Astyanax saguazu Casciotta, Almirón and Azpelicueta, 2003 (10.5\%). On the other hand, Hoplias malabaricus (Bloch, 1794), Hypostomus luteus (Godoy, 1980) and Schizodon nasutus Kner, 1858, were rare, totaling less than $0.1 \%$. In biomass, Hypostomus isbrueckeri Reis, Weber and Malabarba, 1990 (18.5\%), Astyanax xiru $(13.5 \%)$ and Rhamdia quelen (Quoy and Gaimard, 1824) $(10.1 \%)$ were the most representative, whereas Australoheros taura Ottoni and Cheffe, 2009, Astyanax procerus Lucena, Castro and Bertaco, 2013 and Hyphessobrycon sp., contributed with only $0.3 \%$ (Tab. 2).

In general, the most representative in number and biomass were the guilds herbivorous $(23.9 \%)$ and piscivorous (24.6\%), respectively (Fig. 2). The guild aquatic insectivorous was composed of five species, of small and medium size, in which $A$. saguazu was the one that contributed most in numerical abundance (51\%). Two species represented the carnivorous guild, represented numerically mainly by $R$. quelen $(80 \%)$. The detritivorous guild included eight species, mainly of medium size, and the most numerically abundant was $H$. isbrueckeri 
(64.8\%). The herbivorous guild was represented by three species, of which the most numerically abundant were $A$. xiru (89.7\%) and $A$. dissensus (10.2\%). Five small species composed the iliophagous guild, of which S. biornata and S. brevipinna were the most numerically abundant $(66.1 \%$ and $22 \%$, respectively). The omnivorous guild was composed of five species, mainly small-sized, and $A$. paris was the most numerically representative species $(83.8 \%)$. The piscivorous guild exhibited the highest richness, with 10 species, mainly of medium and large sizes, especially $O$. brevioris (37.9\%) and C. celidochilus (18.7\%) (Tab. 2).

Along the Pelotas River, regarding the species richness, there was no pattern related to the longitudinal

Tab. 1. Environmental characteristics and physicochemical water variables (mean and standard deviation) measured along the Pelotas River, between 2013 and 2014, in Upper Uruguay ecoregion.

\begin{tabular}{|c|c|c|c|c|c|c|}
\hline Sites & S1 & \$2 & S3 & S4 & S5 & S6 \\
\hline Latitude & $28^{\circ} 22^{\prime} 49^{\prime \prime} \mathrm{S}$ & $28^{\circ} 28^{\prime} 19^{\prime \prime} \mathrm{S}$ & $28^{\circ} 26^{\prime} 25^{\prime \prime} \mathrm{S}$ & $28^{\circ} 28^{\prime} 46^{\prime \prime} \mathrm{S}$ & $28^{\circ} 29^{\prime} 20^{\prime \prime} \mathrm{S}$ & $28^{\circ} 26^{\prime} 43.8^{\prime \prime} \mathrm{S}$ \\
\hline Longitude & $49^{\circ} 48^{\prime} 31^{\prime \prime O}$ & $49^{\circ} 48^{\prime} 60^{\prime \prime} \mathrm{O}$ & $49^{\circ} 53^{\prime} 25^{\prime \prime} \mathrm{O}$ & $50^{\circ} 02^{\prime} 36^{\prime \prime} \mathrm{O}$ & $49^{\circ} 51^{\prime} 57^{\prime \prime O}$ & $50^{\circ} 17^{\prime} 48.4^{\prime \prime} \mathrm{O}$ \\
\hline Altitude (m) & 1089 & 980 & 939 & 867 & 850 & 782 \\
\hline Width (m) & 35 & 80 & 70 & 100 & 150 & 100 \\
\hline Flow & $\begin{array}{l}\text { Rapid waters } \\
\text { and backwaters }\end{array}$ & $\begin{array}{l}\text { Rapid waters } \\
\text { and deep wells }\end{array}$ & Rapid waters & Moderate flow & $\begin{array}{l}\text { Moderate flow } \\
\text { and backwaters }\end{array}$ & $\begin{array}{c}\text { Backwater and } \\
\text { rapid waters }\end{array}$ \\
\hline River banks & $\begin{array}{l}\text { Approximately } \\
10 \mathrm{~m} \text { forested }\end{array}$ & $\begin{array}{l}\text { RB preserved } \\
\text { with more } \\
\text { than } 50 \mathrm{~m}, \\
\text { LB with approx. } \\
10 \mathrm{~m} \text { forested. } \\
\text { Presence of } \\
\text { Araucaria }\end{array}$ & $\begin{array}{l}\text { Well preserved } \\
\text { area, with } \\
\text { ample protection } \\
\text { of the banks }\end{array}$ & $\begin{array}{l}\text { RB preserved } \\
\text { with Araucarias } \\
\text { and LB approx. } \\
10 \mathrm{~m} \text { forested }\end{array}$ & $\begin{array}{l}\text { RB with mat of } \\
\text { approx. } 20 \mathrm{~m} . \\
\text { LB well } \\
\text { preserved with } \\
\text { presence of } \\
\text { Araucaria }\end{array}$ & $\begin{array}{l}\text { Presence of } \\
\text { riparian } \\
\text { vegetation } \\
\text { of } 50 \mathrm{~m}\end{array}$ \\
\hline Land uses in the surroundings & $\begin{array}{l}\text { Extensive cattle } \\
\text { raising, agriculture } \\
\text { and apple } \\
\text { cultivation }\end{array}$ & $\begin{array}{c}\text { Apple } \\
\text { cultivation } \\
\text { and extensive } \\
\text { cattle raising }\end{array}$ & $\begin{array}{l}\text { Small areas } \\
\text { of apple } \\
\text { cultivation and } \\
\text { pasture }\end{array}$ & Pasture & Pasture & $\begin{array}{l}\text { Livestock and } \\
\text { diverse family } \\
\text { culture }\end{array}$ \\
\hline Electric conductivity $\left(\mu \mathrm{S} \mathrm{cm}^{-1}\right)$ & $21.9 \pm 2.1$ & $22.1 \pm 1$ & $27.3 \pm 3.9$ & $24.1 \pm 5.8$ & $21.7 \pm 2.9$ & $19.8 \pm 2.9$ \\
\hline Water temperature $\left({ }^{\circ} \mathrm{C}\right)$ & $18 \pm 7.1$ & $18.1 \pm 6.4$ & $18.9 \pm 8.2$ & $19.6 \pm 7$ & $19.3 \pm 6.5$ & $20.1 \pm 7.2$ \\
\hline $\mathrm{pH}$ & $6.5 \pm 0.3$ & $6.3 \pm 0.3$ & $6.5 \pm 0.5$ & $6.5 \pm 0.4$ & $6.5 \pm 0.5$ & $6.5 \pm 0.3$ \\
\hline Alkalinity $\left(\mathrm{mg} \mathrm{L}^{-1}\right)$ & $9.6 \pm 1.5$ & $9.9 \pm 2.1$ & $12.9 \pm 3.9$ & $10.8 \pm 3.1$ & $9.8 \pm 1.9$ & $8 \pm 1$ \\
\hline $\mathrm{DO}\left(\mathrm{mg} \mathrm{L}^{-1}\right)$ & $8.6 \pm 1.2$ & $8.1 \pm 1.3$ & $8.9 \pm 1.1$ & $8.5 \pm 1.1$ & $8.9 \pm 1.5$ & $8.4 \pm 1.5$ \\
\hline $\mathrm{DO} \% \mathrm{SAT}$ & $89.1 \pm 10.1$ & $84.2 \pm 9$ & $94 \pm 9.8$ & $90.9 \pm 3.8$ & $96.1 \pm 4.4$ & $90.7 \pm 5.1$ \\
\hline Turbidity & $7.4 \pm 2.3$ & $7.9 \pm 7.4$ & $7.4 \pm 0.3$ & $9.8 \pm 5.6$ & $7.8 \pm 2.9$ & $8.9 \pm 3$ \\
\hline Transparency (m) & $1.5 \pm 0.9$ & $1.5 \pm 0.7$ & $1.7 \pm 0.6$ & $1.4 \pm 0.7$ & $1.2 \pm 0.2$ & $2.5 \pm 0.3$ \\
\hline Color (uH) & $22.8 \pm 6.4$ & $22.9 \pm 13.1$ & $19.8 \pm 6.2$ & $20 \pm 8.7$ & $17.8 \pm 4.8$ & $24.3 \pm 5.9$ \\
\hline Organic nitrogen $\left(\mathrm{mg} \mathrm{L}^{-1}\right)$ & $0.82 \pm 0.18$ & $0.7 \pm 0.21$ & $0.65 \pm 0.14$ & $0.88 \pm 0.36$ & $0.88 \pm 0.15$ & $0.93 \pm 0.24$ \\
\hline Ammonia nitrogen $\left(\mathrm{mg} \mathrm{L}^{-1}\right)$ & $0.11 \pm 0.11$ & $0.08 \pm 0.08$ & $0.09 \pm 0.09$ & $0.08 \pm 0.09$ & $0.08 \pm 0.09$ & $0.05 \pm 0.08$ \\
\hline Total nitrogen $\left(\mathrm{mg} \mathrm{L}^{-1}\right)$ & $0.7 \pm 0.45$ & $0.68 \pm 0.47$ & $0.67 \pm 0.42$ & $0.77 \pm 0.59$ & $0.74 \pm 0.51$ & $0.68 \pm 0.44$ \\
\hline Nitrite $\left(\mathrm{mg} \mathrm{L}^{-1}\right)$ & $0.01 \pm 0.004$ & $0.01 \pm 0.005$ & $0.01 \pm 0.003$ & $0.01 \pm 0.004$ & $0.01 \pm 0.004$ & $0.01 \pm 0.004$ \\
\hline Nitrate $\left(\mathrm{mg} \mathrm{L}^{-1}\right)$ & $0.59 \pm 0.35$ & $0.59 \pm 0.42$ & $0.57 \pm 0.39$ & $0.68 \pm 0.55$ & $0.66 \pm 0.46$ & $0.62 \pm 0.43$ \\
\hline Organic phosphorus (mg L $\mathrm{L}^{-1}$ ) & $0.011 \pm 0.003$ & $0.011 \pm 0.006$ & $0.015 \pm 0.006$ & $0.016 \pm 0.006$ & $0.012 \pm 0.003$ & $0.011 \pm 0.004$ \\
\hline Inorganic phosphorus $\left(\mathrm{mg} \mathrm{L}^{-1}\right)$ & $0.007 \pm 0.004$ & $0.006 \pm 0.001$ & $0.008 \pm 0.002$ & $0.011 \pm 0.006$ & $0.007 \pm 0.002$ & $0.008 \pm 0.003$ \\
\hline Total phosphorus (mg L $\mathrm{m}^{-1}$ ) & $0.018 \pm 0.004$ & $0.017 \pm 0.006$ & $0.023 \pm 0.004$ & $0.027 \pm 0.011$ & $0.019 \pm 0.003$ & $0.019 \pm 0.005$ \\
\hline $\mathrm{BOD}\left(\mathrm{mg} \mathrm{L}^{-1}\right)$ & $4.9 \pm 2.4$ & $2.8 \pm 0.9$ & $4.8 \pm 1.9$ & $4.3 \pm 1.8$ & $4.5 \pm 0.9$ & $3.9 \pm 2.2$ \\
\hline $\operatorname{COD}\left(\mathrm{mg} \mathrm{L}^{-1}\right)$ & $8.6 \pm 5.6$ & $9.8 \pm 7.5$ & $10.5 \pm 7.2$ & $13.1 \pm 7.5$ & $18.1 \pm 13$ & $15.5 \pm 18.2$ \\
\hline Total solids (mg L'-1) & $47 \pm 39.9$ & $75.7 \pm 60$ & $96.2 \pm 100.1$ & $100.5 \pm 107.1$ & $94 \pm 77.6$ & $55.5 \pm 83.2$ \\
\hline Suspended solids ( $\mathrm{mg} \mathrm{L}^{-1}$ ) & $4.8 \pm 6.2$ & $19.7 \pm 36$ & $37.3 \pm 47.3$ & $20 \pm 30.6$ & $20.3 \pm 27.8$ & $21.2 \pm 32$ \\
\hline Dissolved solids $\left(\mathrm{mg} \mathrm{L}^{-1}\right.$ ) & $42.1 \pm 34.5$ & $56 \pm 35.2$ & $59 \pm 56.1$ & $80.5 \pm 77.6$ & $73.6 \pm 52$ & $34.3 \pm 51.8$ \\
\hline Chlorophyll- $a\left(\mu \mathrm{g} \mathrm{L}^{-1}\right)$ & $1.4 \pm 1.5$ & $0.7 \pm 1.1$ & $0.5 \pm 0.2$ & $0.1 \pm 0.2$ & $0.8 \pm 0.8$ & $0.6 \pm 0.7$ \\
\hline
\end{tabular}

$R B$, right bank; $L B$, left bank; $D O$, dissolvid oxygen; \%SAT, percent saturation; $B O D$, biochemical oxygen demand; COD, chemical oxygen demand. 
gradient. Higher richness of aquatic insectivorous was observed in $\mathrm{S} 1$ and $\mathrm{S} 5$, detritivorous, in $\mathrm{S} 3$ and $\mathrm{S} 4$, and in S6, iliophagous. In numerical abundance, the most representative guilds were herbivorous ( $\mathrm{S} 1$ and $\mathrm{S} 3$ ), aquatic insectivorous (S2), detritivorous/aquatic insectivorous (S4 and S5) and iliophagous (S6). In biomass, stood out herbivorous (S1), carnivorous (S2), detritivorous (S3) and piscivorous in the other sites downstream (Fig. 2).

The composition of the trophic guilds along the
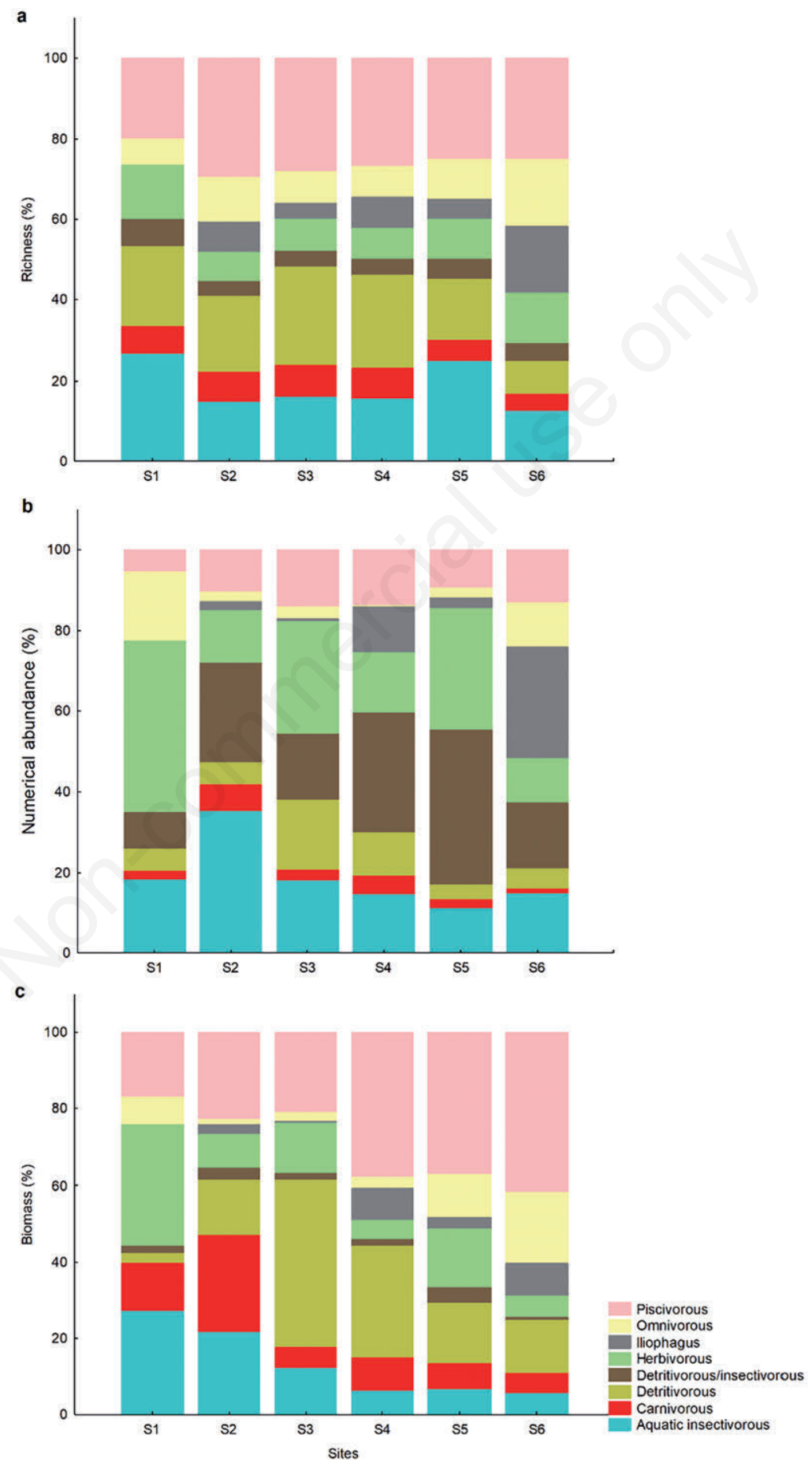

Fig. 2. Relative frequency of the: species richness (a), numerical abundance (b) and biomass (c) according to trophic guild along the longitudinal gradient Pelotas River, between 2013 and 2014, in Upper Uruguay Ecoregion. 
longitudinal gradient of the Pelotas River presented richness, numerical abundance and biomass significantly different between the sites sampled (PseudoF $=18.04$; $\mathrm{P}=0.001 ; \quad$ PseudoF $=9.04 ; \quad \mathrm{P}=0.001, \quad \mathrm{PseudoF}=64.8 ;$ $\mathrm{P}=0.001$, respectively) and between periods (PseudoF=41.0; $\mathrm{P}=0.001$, PseudoF $=10.54 ; \quad \mathrm{P}=0.001$; $\mathrm{PseudoF}=3.36 ; \mathrm{P}=0.005$, respectively), with no significant interaction between the factors (PseudoF=-0.97; $\mathrm{P}=1$, $\mathrm{PseudoF}=-7.71 ; \mathrm{P}=1, \mathrm{PseudoF}=0.82 ; \mathrm{P}=0.55$, respectively).

The first two axes of RLQ with eigenvalues of 0.15 and 0.06 for axes 1 and 2, respectively, accounted for $56.2 \%$ and $22.1 \%$ of the co-inertia and related the environmental characteristics of the sampling sites with the trophic guilds of the species (Fig. 3, Supplementary Tab. 2). The first RLQ axis was positively correlated with vegetation cover and chlorophyll- $a$, and negatively correlated with width, inorganic phosphorus and total solids. The second RLQ axis was positively correlated with chlorophyll- $a$ and inorganic phosphorus, and negatively with temperature, BOD and conductivity (Fig. 3a). The upstream sites (S1, S2 and S3) were segregated positively on RLQ axis 1 and correlations between trophic guilds in this axis indicated that the abundance of the guilds omnivorous, aquatic insectivorous and herbivorous increases with higher values of chlorophyll- $a$ and vegetation cover (Fig. 3 b,c). On the other hand, the abundance of the guilds iliophagous, detritivorous/ insectivorous and piscivorous increases with higher values of width in the downstream sites (S4, S5 and S6) (Fig. 3 b,c). In turn, axis 2 segregated negatively detritivorous, correlated with higher values of BOD and temperature (Fig. 3b). Thus, it was possible to verify strong relationships between the local environmental variables and the composition of the trophic guilds in the sites distributed along the Pelotas River (Fig. 4, Supplementary Tab. 3). By the fourth-corner

Tab. 2. Fish species recorded in the study area. Systematic positions were based on Nelson (2006) for all orders, and the families of the order Siluriformes; Reis et al. (2003) for others families, except Characidae that follow Mirande (2009). Vouchers specimens: individuals deposited in Ichthyology Collection of GERPEL (CIG) and Fish Collection of Nupélia (NUP).

\begin{tabular}{|c|c|c|c|c|c|c|}
\hline Taxonomic position/species & $\begin{array}{l}\text { Numerical } \\
\text { proportion }\end{array}$ & $\begin{array}{c}\text { Biomass } \\
\text { ratio }\end{array}$ & SL $(\mathrm{cm})$ & $\begin{array}{l}\text { Trophic } \\
\text { guild }\end{array}$ & Size & Voucher \\
\hline \multicolumn{7}{|l|}{ CHARACIFORMES } \\
\hline \multicolumn{7}{|l|}{ Parodontidae } \\
\hline Apareiodon affinis (Steindachner, 1879) & 0.13 & 0.06 & $9.2-11.5$ & Iliophagous*1 & Small & CIG 2270 \\
\hline \multicolumn{7}{|l|}{ Curimatidae } \\
\hline Steindachnerina biornata (Braga and Azpelicueta, 1987) & 2.89 & 2.7 & $4.4-14$ & Iliophagous*2 & Small & CIG 2334 \\
\hline Steindachnerina brevipinna (Eigenmann and Eigenmann, 1889) & 0.96 & 0.32 & $2-8.6$ & Iliophagous*2 & Small & CIG 2295 \\
\hline \multicolumn{7}{|l|}{ Anostomidae } \\
\hline Leporinus amae Godoy (1980) & 2.4 & 2.67 & $7.4-15.7$ & $\begin{array}{c}\text { Aquatic } \\
\text { insectivorous }\end{array}$ & Small & CIG 2285 \\
\hline Schizodon nasutus Kner (1858) & 0.03 & 0.32 & 27 & Herbivorous $* 1$ & Large & CIG 2373 \\
\hline \multicolumn{7}{|l|}{ Characidae } \\
\hline Astyanax aff. fasciatus (Cuvier, 1819) & 0.68 & 0.35 & $6.9-11.8$ & Omnivorous & Small & CIG 2276 \\
\hline Astyanax dissensus Lucena and Thofehrn (2013) & 2.63 & 0.33 & $2.3-10.2$ & Herbivorous & Small & CIG 2265/2296 \\
\hline Astyanax paris Azpelicueta, Almirón and Casciotta (2002) & 5.42 & 1.7 & $2.7-10.1$ & Omnivorous & Small & CIG 2276/2292 \\
\hline Astyanax cf. procerus Lucena, Castro and Bertaco (2013) & 0.05 & 0.01 & 6- 6.1 & Omnivorous*3 & Small & NUP 18138 \\
\hline Astyanax saguazu Casciotta, Almirón and Azpelicueta (2003) & 10.5 & 2.56 & $2.8-12.1$ & $\begin{array}{c}\text { Aquatic } \\
\text { insectivorous }\end{array}$ & Small & CIG 2271/2629 \\
\hline Astyanax xiru Lucena, Castro and Bertaco (2013) & 23.25 & 13.49 & $2.4-12.9$ & Herbivorous & Small & CIG 2267/2338 \\
\hline Bryconamericus patriciae da Silva (2004) & 20.72 & 2.27 & $2-8.4$ & $\begin{array}{l}\text { Detritivorous/ } \\
\text { aquatic } \\
\text { insectivorous }\end{array}$ & Small & CIG 2257/2362 \\
\hline Oligosarcus brevioris Menezes (1987) & 3.91 & 9.32 & $2.2-25.6$ & Piscivorous & Medium & CIG 2341 \\
\hline Oligosarcus jenynsii (Günther, 1864) & 0.83 & 2.29 & $8-24.7$ & Piscivorous & Medium & CIG 2331 \\
\hline \multicolumn{7}{|l|}{ Acestrorhynchidae } \\
\hline Acestrorhynchus pantaneiro Menezes (1992) & 0.03 & 0.04 & 16.4 & Piscivorous*4 & Medium & CIG 2310 \\
\hline \multicolumn{7}{|l|}{ Erythrinidae } \\
\hline Hoplias australis Oyakawa and Mattox (2009) & 0.05 & 0.59 & $26.1-29.1$ & Piscivorous $* 5$ & Large & CIG 2368 \\
\hline Hoplias lacerdae Miranda Ribeiro (1908) & 0.68 & 9.66 & $9.6-54$ & Piscivorous & Large & CIG 2332 \\
\hline Hoplias malabaricus (Bloch, 1794) & 0.03 & 0.31 & $27.1-27.1$ & Piscivorous $* 5$ & Large & CIG 2365 \\
\hline
\end{tabular}


approach, significant positive correlations were observed between width and the detritivorous/insectivorous, iliophagous and piscivorous guilds (P-value adj. $=0.02$; 0.02 and 0.03 , respectively); between $\mathrm{DBO}$ and temperature with detritivorous guild ( $\mathrm{P}$-value adj. $=0.01$ and 0.04 , respectively). Negative correlations were significant only between turbidity and the carnivorous guild (P-value adj. $=0.01)$.

\section{DISCUSSION}

The Pelotas River showed a high richness represented by eight trophic guilds, as well as a diversified trophic structure that varied spatially along the river continuum. Differences in the composition of the guilds between the sampling sites were mainly related to the upstream presence of small-sized Astyanax species. On the other hand, in the downstream stretches it was observed that the most abundant species were small- to large-sized belonging to the guilds iliophagous (Steindachnerina), detritivorous (Hypostomus) and piscivorous (Oligosarcus and Crenicichla), respectively. We also verified that the use of allochthonous resources decreased along the longitudinal gradient (upstream-downstream), being the opposite for autochthonous resources. This pattern is expected by Vanote et al. (1980), meantime, we observed also that local environmental variables played an additional role in trophic structuring along the Pelotas River gradient.

Environmental conditions coupled with biotic interactions have a strong effect on the structuring and functional organization of fish assemblages (Hoeinghaus

Table 2. Continued from previous page.

\begin{tabular}{|c|c|c|c|c|c|c|}
\hline Taxonomic position/species & $\begin{array}{l}\text { Numerical } \\
\text { proportion }\end{array}$ & $\begin{array}{c}\text { Biomass } \\
\text { ratio }\end{array}$ & SL $(\mathrm{cm})$ & $\begin{array}{l}\text { Trophic } \\
\text { guild }\end{array}$ & Size & Voucher \\
\hline \multicolumn{7}{|l|}{ SILURIFORMES } \\
\hline \multicolumn{7}{|l|}{ Loricariidae } \\
\hline Hemiancistrus fuliginosus Cardoso and Malabarba (1999) & 4.9 & 7.17 & $5.9-22.6$ & $\begin{array}{c}\text { Aquatic } \\
\text { insectivorous } * 6\end{array}$ & Small & CIG 2329 \\
\hline Hypostomus commersoni Valenciennes (1836) & 0.13 & 0.61 & $16.3-21.3$ & Detritivorous*7 & Large & CIG 2366 \\
\hline Hypostomus isbrueckeri Reis, Weber and Malabarba (1990) & 5.24 & 18.65 & $6.5-24.9$ & Detritivorous*7 & Medium & CIG 2354 \\
\hline Hypostomus luteus (Godoy, 1980) & 0.03 & 0.11 & 17 & Detritivorous*7 & Large & NUP 16848 \\
\hline Pareiorhaphis hystrix (Pereira and Reis, 2002) & 0.08 & 0.04 & 8-9.9 & Detritivorous $* 8$ & Small & CIG 2333 \\
\hline Rineloricaria anitae Ghazzi (2008) & 0.39 & 0.15 & $10.2-14.4$ & Detritivorous $* 9$ & Medium & CIG 2297 \\
\hline Rineloricaria capitonia Ghazzi (2008) & 1.07 & 0.44 & $10.1-15.3$ & Detritivorous $* 9$ & Medium & CIG 2299 \\
\hline Rineloricaria reisi Ghazzi (2008) & 0.83 & 0.33 & $8.7-15.3$ & Detritivorous $* 9$ & Medium & CIG 2324 \\
\hline Rineloricaria tropeira Ghazzi (2008) & 0.31 & 0.18 & $11.6-15.1$ & Detritivorous $* 9$ & Medium & CIG 2298 \\
\hline \multicolumn{7}{|l|}{ Heptapteridae } \\
\hline Rhamdella longiuscula Lucena and da Silva (1991) & 2.66 & 2.21 & $9.2-20.8$ & $\begin{array}{c}\text { Aquatic } \\
\text { insectivorous }\end{array}$ & Medium & CIG 2349 \\
\hline Rhamdia quelen (Quoy and Gaimard, 1824) & 2.87 & 10.13 & $11.1-34.2$ & Carnivorous & Large & CIG 2369 \\
\hline \multicolumn{7}{|l|}{ Pimelodidae } \\
\hline Iheringichthys labrosus (Lütken, 1874) & 0.13 & 0.38 & $14.3-20.5$ & $\begin{array}{c}\text { Aquatic } \\
\text { insectivorous*1 }\end{array}$ & Medium & CIG 2326 \\
\hline Pimelodus maculatus Lacepède (1803) & 0.29 & 3.41 & $22.9-32$ & Omnivorous $* 10$ & Medium & CIG 2360 \\
\hline \multicolumn{7}{|l|}{ ATHERINIFORMES } \\
\hline \multicolumn{7}{|l|}{ Atherinopsidae } \\
\hline Odontesthes sp. & 0.73 & 1.54 & $2.4-26.9$ & Carnivorous*11 & Medium & CIG 2360 \\
\hline \multicolumn{7}{|l|}{ PERCIFORMES } \\
\hline \multicolumn{7}{|l|}{ Cichlidae } \\
\hline Australoheros taura Ottoni and Cheffe (2009) & 0.03 & 0.04 & $7.2-9.2$ & Iliophagous $* 12$ & Small & CIG 2246 \\
\hline Crenicichla celidochilus Casciotta (1987) & 1.93 & 2.08 & $5.8-21.1$ & Piscivorous $* 12$ & Medium & NUP 18131 \\
\hline Crenicichla igara Lucena and Kullander (1992) & 2.5 & 2.74 & $5.1-19.4$ & Piscivorous $* 12$ & Small & CIG 2279 \\
\hline Crenicichla missioneira Lucena and Kullander (1992) & 0.21 & 0.31 & $13.1-15.6$ & Piscivorous $* 12$ & Small & CIG 2307 \\
\hline Crenicichla tendybaguassu Lucena and Kullander (1992) & 0.13 & 0.19 & $8.1-17$ & Piscivorous $* 12$ & Small & CIG 2254 \\
\hline Geophagus brasiliensis (Quoy and Gaimard, 1824) & 0.36 & 0.31 & $2.3-12.1$ & Iliophagous $* 13$ & Small & CIG 2248 \\
\hline
\end{tabular}

SL, standard lengths (minimum - maximum); size, small $(<20 \mathrm{~cm}$ ), medium (between 20 and $40 \mathrm{~cm}$ ), large $(>40 \mathrm{~cm}$ ) (sensu Baumgartner et al., 2012); $*$ the trophic group was inferred by consulting bibliographical references (superscript numbers): 1. Teixeira and Bennemann (2007); 2. Giora and Fialho (2003); 3. Bonato et al. (2017); 4. Meurer and Zaniboni-Filho (2012); 5. Corrêa and Piedras (2009); 6. Langoni (2015); 7. Copatti and Copatti (2011); 8. Dias and Fialho (2011); 9. Ghazzi, 2008; 10. Lobon-Cervia and Bennemann (2000); 11. Rodrigues and Bemvenuti (2001); 12. Burress et al. (2012); 13. Meschiatti (1995). 

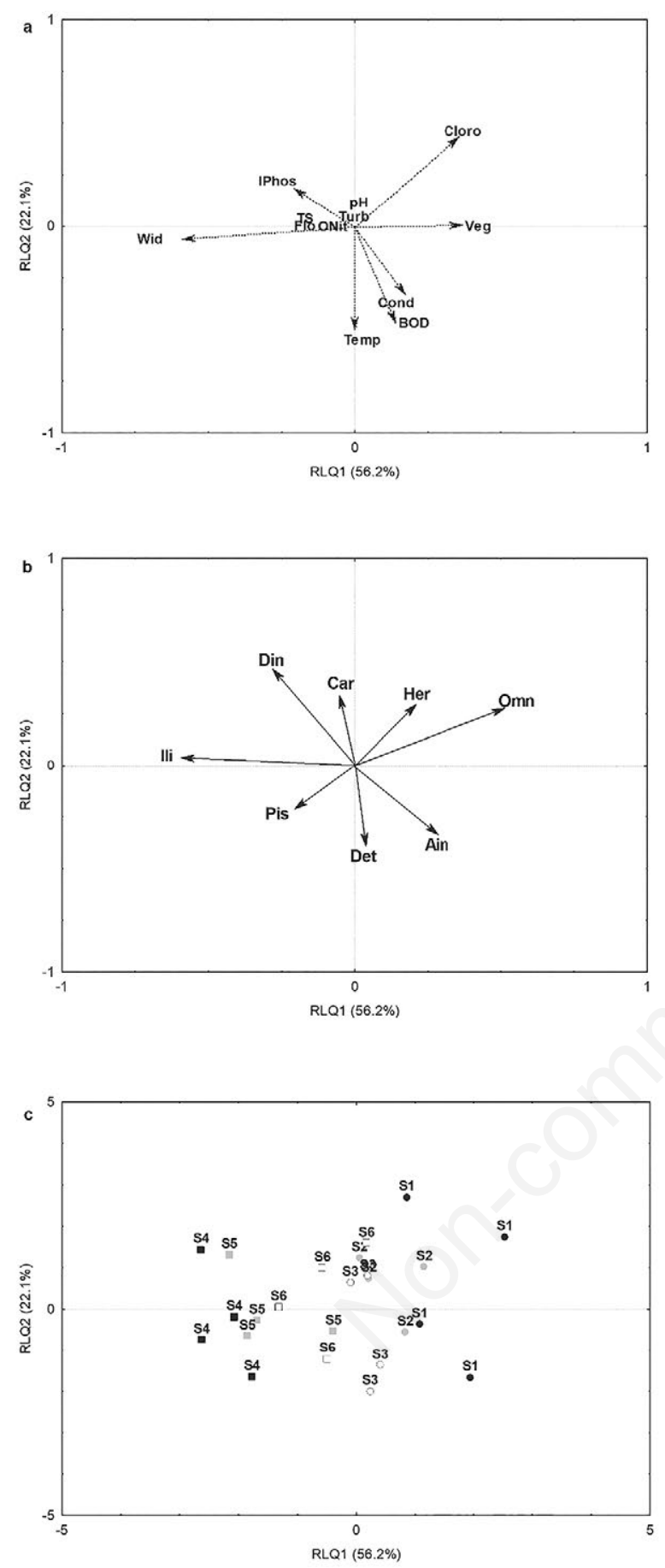

Fig. 3. Relationship between environmental variables and the first two axes of the RLQ analysis (a) of fish species along the longitudinal gradient Pelotas River, between 2013 and 2014, in Upper Uruguay ecoregion. Trait coefficients (b) and the sites scores (c) are also shown. Wid, width; Temp, temperature; Cond, conductivity; BOD, biochemical oxygen demand; Veg, vegetal cover; Cloro, chlorophyll- $a$; Turb, turbidity; TS, total solids; Flo, flow; ONit, organic nitrogen; IPhos, phosphorus inorganic; Omn, omnivorous; Her, herbivorous; Ain, aquatic insectivorous; Car, carnivorous; Det, detritivorous, Pis, piscivorous; Din, detritivorous/ insectivorous; Ili, iliophagous. et al., 2011). Differences in the distribution of trophic guilds showed a relationship between the use of food resources and the environmental characteristics evaluated. Higher abundances of herbivorous and omnivorous were positively related to higher vegetation cover and chlorophyll- $a$ in upstream sites, which evidences the strong relationship with the input of allochthonous material. The proportion of vegetation cover and the strong water flow in these upstream stretches are more limiting to primary production, but provide input of allochthonous resources, making them energetically favorable for some fish species, especially herbivorous. This fact is reinforced by the high abundance of Astyanax xiru at upstream sites. This is species also is reported as herbivorous in studies conducted in adjacent basin (Bonato et al., 2018). Moreover, omnivorous species, given their trophic plasticity (A. aff. fasciatus, A. cf. procerus and $P$. maculatus), are also favored by variations in the availability of resources. In addition, these species are considered more generalist and have morphologies that enable the exploitation of different compartments of the habitat. This strong relationship between morphology, foraging efficiency and habitat use has been well reported, especially for the genus Astyanax (Mise et al., 2013; Neves et al., 2015; Bonato et al., 2018).

In the downstream sites, piscivorous, iliophagous and detritivorous, considered more specialist guilds, were significantly correlated with the increase in width, total solids, inorganic phosphorus and temperature, indicating that these environmental variables favor the success of these guilds downstream. In this context, piscivorous was the guild that exhibited the greatest species richness and was composed mainly by Oligosarcus, Crenicichla and Hoplias. These species of medium and large size present advantages in stretches characterized by greater width and depth, considering their swimming ability and visual acuity to capture prey. This finding is reinforced by Colloca et al. (2009), who observed a significant correlation between body size of predators and depth. Piscivorous species with a prey pursuit tactics, such as those of the genus Oligosarcus studied here, present a set of characteristics that increase the success of capture of mobile prey in the water column, such as compressed body together with terminal mouth and canine teeth (Nunes and Hartz, 2006). On the other hand, species that exhibit an ambush feeding tactics, such as Hoplias (Oliveira et al., 2010), have an advantage in environments with high total solids load, as well as turbidity, due to the fact that species with low visual acuity are disadvantaged, making them potential prey that can be captured.

The increase in river width reduces the proportion of shaded water promoted by riparian vegetation, thus exposing the river bed to a higher solar incidence and, consequently, higher temperatures. These characteristics 
influence the structural complexity of habitats, and in rivers, they alter the supply and availability of resources besides influence the co-occurrence of species (Suarez et al., 2007; Carvalho and Tejerina-Garro, 2015). In this aspect, the increase in the availability of fine organic matter (like detritus; fragmented by the hydrological action and macroinvertebrates downstream) favor the detritivorous and iliophagous guilds (Nimet et al., 2015). This is especially due to the trophic specializations exhibited by species belonging to these specialist guilds. For example, the presence of long intestine is characteristic of species of the family Loricariidae (Delariva and Agostinho, 2001) and Curimatidae (Bowen, 1983), which allows the absorption of detritus. In our study, these species were mainly represented by the genus Hypostomus and Steindachnerina, respectively. Besides the greater availability of organic detritus downstream, a greater solar incidence and the increase in temperature also promotes increased primary productivity, especially through the growth of periphytic algae attached to the rocky bottom (Pagotto et al., 2011; Wolff et al., 2013; Abilhoa et al., 2016). The solar radiation acts directly on the photosynthesis rate and determines the depth of the euphotic zone, whereas the temperature can act on phytoplankton productivity directly on the physiology of organisms and indirectly on the distribution of nutrients in the euphotic zone (Esteves, 2011). Thus, these environmental variables conferred an advantage to the detritivorous and iliofagous guilds, due to the increase in the availability of resource.

In large South American rivers with extensive floodplains, the high abundance of detritus/sediments favors the establishment of species with morphological characteristics specialized in efficient use of this type of resource, such as detritivorous (Delariva and Agostinho, 2001; Abujanra et al., 2009). In our study, the presence of several representatives with detritivorous habit (e.g., Hypostomus and Rineloricaria) at the downstream sites (S4, S5 and S6), demonstrates the dependence on solid materials coming from the displacement along the gradient. Suspended material tends to be deposited further downstream sites, where the width and depth are larger, as opposed to water velocity. This material provides energy sources to establish a food web based on detritus.

\section{Vegetal cover Clorophyll - a}

\section{Width, inorganic phosphorous, total solids}

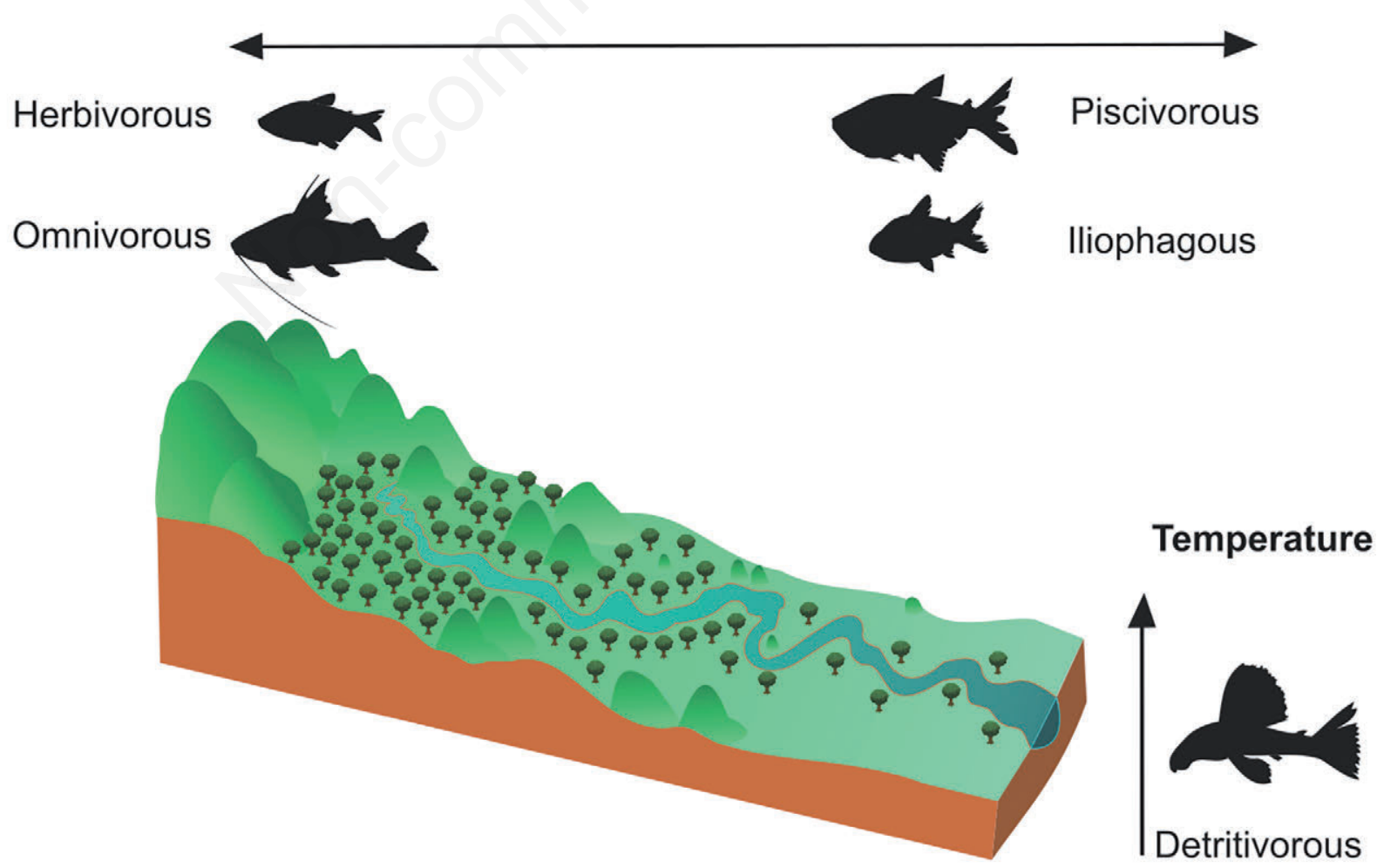

Fig. 4. Schematic representation summarizing the results of the RLQ analysis. Increasing width (from upstream to downstream sites). 
Our results support the hypothesis of a proportional shift from generalist guilds, such as herbivorous and omnivorous to those more specialized, such as detritivorous and piscivorous, along the longitudinal gradient of the river. In this sense, we highlight the negative correlation between turbidity and carnivorous guild. In downstream stretches, in addition to the larger dimensions and increment of detritus, as discussed above, the lower flow velocity favors the sedimentation and, consequently, greater transparency. Added to this process are important increases in the richness of food sources, which together with higher primary productivity favor the selection of more specialized trophic groups, especially those linked to higher trophic levels. In this sites, carnivorous species, mainly the persecutors, are favored (Angermeier and Karr, 1983; Ibañez et al., 2007; Wolff et al., 2013). This switch of trophic functions can be related to the decrease in altitude, which affects longitudinal variations in environmental parameters (Angermeier and Karr, 1983; Pouilly et al., 2006). In temperate regions, for example large European rivers, the richness of trophic guilds also increases downstream, and there are clear changes in guild structuring. However, the fish fauna is mostly composed of generalists and the trophic guild specializations are more constrained (Aarts and Nienhuis, 2003; Howeth et al., 2016; Macnaughton et al., 2016) than those verified in our study.

In the neotropical region, in rivers under strong influence of hydrological regimes, such as the Xingu River, the functional diversity is related to processes that promote functional similarity (for example, abiotic filtration), which strongly influence communities (Fitzgerald et al., 2017). Furthermore, in rivers of the Tocantins-Araguaia River basin, Carvalho and TejerinaGarro (2015) emphasize that the environmental conditions and spatial components drive the structural complexity of the habitat, consequently, the coexistence of species, since heterogeneous habitats can sustain more species with different traits. In this regard, specialist trophic guilds (detritivorous, iliophagous and piscivorous) are more associated with more stable water flow environments, whereas generalists are more abundant in places with greater hydrological variability (Poff and Allan, 1995). In this scenario, our study follows the longitudinal model and evidences a greater accumulation of energy in food webs in the upstream-downstream direction, which favors the greatest abundance of piscivorous, detritivorous and iliophagous verified in stretches of greater volume and dimensions of river.

Considering the Brazilian scenario whose public policies promote the implantation of small hydropower plants (Pelicice et al., 2017), without considering the changes that occurred after the formation of the reservoirs in sequence, we highlight some considerations based on our results. Cascade reservoirs mainly alter flow velocity, sedimentation, longitudinal connectivity processes and ecotone (Agostinho et al., 2008; Santos et al. 2017). The substitution of lotic for lentic environment causes changes particularly in the water retention time, sediment characteristics, nutrients and limnological variables (Franchi et al., 2014; Schork and Zaniboni-Filho, 2017), which were strongly correlated with selection of trophic guilds in our study. In this sense, questions about the influence of these impoundments on the trophic structure can be raised. It would be reasonable to expect possible implications: i) reduction of the detritivorous and iliophagous guilds due to the alteration of the lotic stretches with rocky bottoms; ii) the increase of generalist guilds and explorers of the water column, such as omnivorous fish; iii) homogenization of the trophic guilds along the longitudinal gradient. Thus, we emphasize the need for further researches that specifically assess the species loss and further impairment in regulated rivers by small hydropower plants in cascade. These studies will contribute towards guiding sustainability policies for the ecosystem services of plateau rivers.

\section{CONCLUSIONS}

Our study verified a marked longitudinal variation in the trophic organization of the fish assemblage along the Pelotas River, where differences in the composition of the guilds suggest specific trophic structuring related to local environmental characteristics. Variables such as vegetation cover, chlorophyll- $a$, width, inorganic phosphorus, total solids and temperature were related to the composition and abundance of trophic guilds along the upstream-downstream gradient, and can be considered as environmental filters. In this way, our results highlight the importance of the contribution from allochthonous sources of energy in upstream stretches, as well as the local variables and the interrelations in the processes of lateral connectivity, along the river continuum. These findings assume a relevant role for conservation and resource management practices, considering that future changes in the dynamics of the Pelotas River due to the construction of small hydropower plants (SHPP) may eliminate or alter the main trophic structuring forces verified here. As a consequence, they will irreversibly alter local environmental characteristics, directly affecting the fish community and the trophic structure.

\section{ACKNOWLEDGMENTS}

We wish thank to Grupo de Pesquisas em Recursos Pesqueiros e limnologia (GERPEL) for field work, provision of data and support for the accomplishment of 
this study, to Claúdio Zawadski, Weferson J. da Graça and Gabriel C. Deprá for help in confirming Hypostomus luteus and Crenicicha celidochilus and Astyanax cf. procerus.

\section{REFERENCES}

Aarts BGW, Nienhuis PH, 2003. Fish zonations and guilds as the basis for assessment of ecological integrity of large rivers. Hydrobiologia 500:157-178.

Abell R, Thieme ML, Revenga C, Bryer M, Kottelat M, Bogutskaya N, Coad B, Mandrak N, Balderas SC, Bussing W, Stiassny MLJ, Skelton P, Allen GR, Unmack P, Naseka A, Ng R, Sindorf N, Robertson J, Armijo E, Higgins JV, Heibel TJ, Wikramanayake E, Olson D, López HL, Reis RE, Lundberg JG, Pérez MHS. Petry P. 2008. Freshwater ecoregions of the world: A new map of biogeographic units for freshwater biodiversity conservation. Bioscience 58:403-414.

Abilhoa V, Valduga MO, Frehse FA, Vitule JRS, 2016. Use of food resources and resource partitioning among five syntopic species of Hypostomus (Teleostei: Loricariidae) in an Atlantic Forest river in southern Brazil. Rev. Bras. Zool. 33:1984-4689.

Abujanra F, Agostinho AA, Hahn, NS, 2009. Effects of the flood regime on the body condition of fish of different trophic guilds in the Upper Paraná River floodplain, Brazil. Braz. J. Biol. 69:469-479.

Affonso IP, Azevedo RF, dos Santos NLC, Dias RM, Agostinho AA, Gomes LC, 2015. Pulling the plug: strategies to preclude expansion of dams in Brazilian rivers with highpriority for conservation. Nat. Conservação 13:199-203.

Agostinho AA, Pelicice FM, Gomes LC, 2008. Dams and the fish fauna of the Neotropical region: impacts and management related to diversity and fisheries. Braz. J. Biol. 68:1119-1132.

Anderson MJ, 2001. A new method for non-parametric multivariate analysis of variance. Austral Ecol. 26:32-46.

Angermeier PL, Karr JR, 1983. Fish communities along environmental gradients in a system of tropical streams. Environ. Biol. Fishes 9:117-135.

Baumgartner G, Pavanelli CS, Baumgartner D, Bifi AG, Debona T, Frana VA, 2012. Peixes do baixo rio Iguaçu. EDUEM, Maringá: 203 pp.

Bicudo CEM, Bicudo RMT, 1970. [Algas de águas continentais brasileiras chave ilustrada para identificação de gêneros].[Book in Portuguese]. Fundação Brasileira para o Desenvolvimento do Ensino de Ciências, São Paulo: 228 pp.

Bonato KO, Burress ED, Fialho CB, Armbruster JW, 2018. Resource partitioning among syntopic Characidae corroborated by gut content and stable isotope analyses. Hydrobiologia 805:311-324.

Bonato KO, Delariva RL, da Silva JC, 2012. Diet and trophic guilds of fish assemblages in two streams with different anthropic impacts in the northwest of Paraná, Brazil. Rev. Bras. Zool. 29:27-38.

Borcard D, Gillet F, Legendre P, 2011. Numerical ecology with R. Springer, New York: 306 pp.

Bowen S, 1983. Detritivory in neotropical fish communities. Environ. Biol. Fishes 9:137-144.

Burress ED, Duarte A, Gangloff MM, Siefferman L, 2013.
Isotopic trophic guild structure of a diverse subtropical South American fish community. Ecol. Freshw. Fish 22:66-72.

Carvalho RA, Tejerina-Garro FL, 2015. Environmental and spatial processes: what controls the functional structure of fish assemblages in tropical rivers and headwater streams? Ecol. Freshw. Fish 24:317-328.

Colloca F, Carpentieri P, Balestri E, Ardizzone G, 2009. Food resource partitioning in a Mediterranean demersal Wsh assemblage: the eVect of body size and niche width. Mar. Biol. 157:565-574.

Connel JH, 1980. Diversity and the coevolution of competitors, or the ghost of competition past. Oikos 35:131-138.

Copatti CE, Copatti RB, 2011. [Variação sazonal e diversidade de peixes do rio Cambará, Bacia do rio Uruguai].[Article in Portuguese]. Biota Neotrop. 11:265-271.

Córdova-Tapia F, Hernández-Marroquín V, Zambrano L, 2017. The role of environmental filtering in the functional structure of fish communities in tropical wetlands. Ecol. Freshw. Fish 00:1-11.

Corrêa F, Piedras SRN, 2009. [Alimentação de Hoplias aff malabaricus (Bloch, 1794) e Oligosarcus robustus Menezes, 1969 em uma lagoa sob influência estuarina, Pelotas, RS].[Article in Portuguese]. Biotemas 22:121-128.

Delariva RL, Agostinho AA, 2001. Relationship between morphology and diets of six neotropical loricariids. J. Fish Biol. 58:832-847.

Delariva RL, Hahn NS, Kashiwaqui EAL, 2013. Diet and trophic structure of the fish fauna in a subtropical ecosystem: impoundment effects. Neotrop. Ichthyol. 11:891-904.

Dias TS, Fialho CB, 2011. Comparative dietary analysis of Eurycheilichthys pantherinus and Pareiorhaphis hystrix: two Loricariidae species (Ostariophysi, Siluriformes) from Campos Sulinos biome, southern Brazil. Iheringia Ser. Zool. 101:49-55.

Dolédec S, Chessel D, Ter Braak CJF, Champely S, 1996. Matching species traits to environmental variables: a new three-table ordination method. Environ. Ecol. Stat. 3:143-166.

Dray S, Dufour AB, 2007. The ade4 package: implementing the duality diagram for ecologists. J. Stat. Softw. 22:1-20.

Dray S, Legendre P, 2008. Testing the species traits-environment relationships: the fourth-corner problem revisited. Ecology $89: 3400-3412$

Dunck B, Algarte VM, Cianciaruso MV, Rodrigues L, 2016. Functional diversity and trait-environment relationships of periphytic algae in subtropical floodplain lakes. Ecol. Indic. 67:257-266.

Esteves FA, 2011. [Fundamentos de limnologia].[Book in Portuguese]. Interciência, Rio de Janeiro: 826 pp.

Esteves KE, Lobo AVP, Faria MDR, 2008. Trophic structure of a fish community along environmental gradients of a subtropical river (Paraitinga River, Upper Tiete River Basin, Brazil). Hydrobiologia 598:373-387.

Félix KK, Yves BK, Edia EO, Martin KK, Allassane O, Germain G, 2013. Effect of dam on the trophic guilds structure of fish assemblages in the Bia River-Lake systems (South-Eastern of Côte d'Ivoire). Bull. Env. Pharmacol. Life Sci. 2:43-51.

Fitzgerald DB, Winemiller KO, Pérez MHS, Sousa LM, 2017. Using trophic structure to reveal patterns of trait-based community assembly across niche dimensions. Funct. Ecol. 31:1135-1144. 
Franchi E, Carosi A, Ghetti L, Giannetto D, Pedicillo G, Pompei L, Lorenzoni M, 2014. Changes in the fish community of the upper Tiber River after construction of a hydro dam. J. Limnol. 73:203-210.

Furlan N, Esteves KE, Quináglia GA, 2013. Environmental factors associated with fish distribution in an urban neotropical river (Upper Tietê River Basin, São Paulo, Brazil). Environ. Biol. Fish 96:77-92.

Gandini CV, Sampaio FAC, Pompeu PS, 2014. Hydropeaking effects of on the diet of a Neotropical fish community. Neotrop. Ichthyol. 12:795-802.

Gerking SD, 1994. Feeding ecology of fish. Academic Press, Califórnia: $416 \mathrm{pp}$.

Ghazzi MS, 2008. [Nove espécies novas do gênero Rineloricaria (Siluriformes, Loricariidae) do rio Uruguai, do sul do Brasil]. Iheringia Ser. Zool. 98:100-122.

Giora J, Fialho CB, 2003. Feeding biology of Steindachnerina brevipinna (Characiformes, Curimatidae) in the Ibicuímirim river, Rio Grande do Sul, Brazil. Iheringia Ser. Zool. 93:277-281.

Goulding M, Carvalho ML, Ferreira EJG, 1988. Rio Negro. Rich life in poor water. Amazonian diversity and food chain ecology as seen through fish communities. SBP Academic Publishing, The Hague: 200 pp.

Hargreaves D, Buckland A, Sheaves M, 2017. Trophic guild concept: factors affecting within guild consistency for tropical estuarine fish. Mar. Ecol. Prog. Ser. 564:175-186.

Hellawell JM, Abel R, 1971. A rapid volumetric method for the analysis of the food of fishes. J. Fish Biol. 3:29-37.

Hill MO, Smith AJE, 1976. Principal component analysis of taxonomic data with multi-state discrete characters. Taxon 25:249-255.

Hoeinghaus DJ, Vieira JP, Costa CS, Bemvenuti CE, Winemiller KO, Garcia AM, 2011. Estuary hydrogeomorphology affects carbon sources supporting aquatic consumers within and among ecological guilds. Hydrobiologia 673:79-92.

Howeth JG, Gantz CA, Angermeier PL, Frimpong EA, Hoff MH, Keller RP, Mandrak NE, Marchetti MP, Olden JD, Romagosa CM, Lodge DM, 2016. Predicting invasiveness of species in trade: climate match, trophic guild and fecundity influence establishment and impact of non-native freshwater fishes. Divers. Distrib. 22:148-160.

Hyslop EJ, 1980. Stomach content analysis: a review of methods and their application. J. Fish Biol. 17:411-429.

Ibañez C, Oberdorff T, Teugels G, Mamononekene V, Lavoué S, Fermon Y, Paugy D, Toham AK, 2007. Fish assemblages structure and function along environmental gradients in rivers of Gabon (Africa). Ecol. Freshw. Fish. 16:315-334.

Kliemann BCK, Delariva RL, 2015. [Pequenas centrais hidrelétricas: cenários e perspectivas no estado do Paraná].[Article in Portuguese]. Ciência e Natura 37:274-284.

Langoni ADS, 2015. [Biologia comparada alimentar de três lolicarídeos (Ostariophysi, Siluriformes) em diferentes riachos da Bacia do Alto Jacuí, Rio Grande do Sul, Brasil].[PhD Thesis in Portuguese]. Universidade Federal do Rio Grande do Sul, Porto Alegre.

Latini JR, Pedlowski MA, 2016. [Examinando as contradições em torno das Pequenas Centrais Hidrelétricas como fontes sustentáveis de energia no Brasil].[Article in Portuguese]. Desenvolvimento e Meio ambiente 37:73-90.
Legendre P, Legendre L, 2012. Numerical ecology. Elsevier, Amsterdam: $852 \mathrm{pp}$.

Leitão RP, Zuanon J, Mouillot D, Leal CG, Hughes RM, Kaufmann PR, Villéger S, Pompeu PS, Kasper D, de Paula FR, Ferraz SFB, Gardner TA, 2017. Disentangling the pathways of land use impacts on the functional structure of fish assemblages in Amazon streams. Ecography 40:1-13.

Loureiro-Crippa VE, Hahn NS, 2006. Use of resources by the fish fauna of a small reservoir (Rio Jordão, Brazil) before and shortly after its filling. Neotrop. Ichthyol. 4:357-362.

Lowe-McConnell RH, 1999. [Estudos ecológicos de comunidades de peixes tropicais].[Book in Portuguese]. EDUSP, São Paulo: 535 pp.

Luz-Agostinho KDG, Bini LM, Fugi R, Agostinho AA, Júlio Jr HF, 2006. Food spectrum and trophic structure of the ichthyofauna of Corumbá reservoir, Paraná river Basin, Brazil. Neotrop. Ichthyol. 4:61-68.

Macnaughton CM, Senay C, Dolinsek I, Bourque G, Maheu A, Lanthier G, Harvey-Lavoie S, Asselin J, Legendre P, Boisclair D, 2016. Using fish guilds to assess community responses to temperature and flow regimes in unregulated and regulated Canadian rivers. Freshwater Biol. 61:1759-1772.

Melles SJ, Jones NE, Schmidt B, 2012. Review of theoretical developments in stream ecology and their inuence on stream classication and conservation planning. Freshwater Biol. 57:415-434.

Mérona B, Santos GM, Almeida RG, 2001. Short term effects of Tucuruí Dam (Amazonia, Brazil) on the trophic organization of fish communities. Environ. Biol. Fish. 60:375-392.

Meschiatti AJ, 1995. [Alimentação da comunidade de peixes de uma lagoa marginal do Rio Mogi-guaçü, SP].[Article in Portuguese]. Acta Limnol. Bras. 7:115-137.

Meurer S, Zaniboni-Filho E, 2012. Reproductive and feeding biology of Acestrorhynchus pantaneiro Menezes, 1992 (Osteichthyes: Acestrorhynchidae) in areas under the influence of dams in the upper Uruguay River, Brazil. Neotrop. Ichthyol. 10:159-166.

Ministério do Meio Ambiente, Secretaria de Recursos Hídricos, 2006. [Caderno da Região Hidrográfica do Uruguai].[Report in Portuguese]. Brasilia: MMA. Accessed: December 2016. Available from: http://www.mma.gov.br/estruturas/161/_ publicacao/161_publicacao03032011023025.pdf

Mirande JM, 2009. Weighted parsimony phylogeny of the family Characidae (Teleostei: Characiformes). Cladistics 25:574-613.

Mise FT, Fugi R, Pagotto JPA, Goulart E, 2013. The coexistence of endemic species of Astyanax (Teleostei: Characidae) is propitiated by ecomorphological and trophic variations. Biota Neotrop. 13:21-28.

Mouillot D, Graham NAJ, Villéger S, Mason NWH, Bellwood DR, 2013. A functional approach reveals community responses to disturbances. Trends Ecol. Evol. 28:167-177.

Mugnai R, Nessimian JL, Baptista DF, 2010. [Manual de identificação de macroinvertebrados aquáticos do estado do Rio de Janeiro].[Book in Portuguese]. Technical Books, Rio de Janeiro: $174 \mathrm{pp}$.

Nelson JS, 2006. Fishes of the world. J. Wiley \& Sons, New York: $615 \mathrm{pp}$. 
Neves MP, Delariva RL, Wolff LL, 2015. Diet and ecomorphological relationships of an endemic, species-poor fish assemblage in a stream in the Iguaçu National Park. Neotrop. Ichthyol. 13:245-254.

Nimet J, Delariva RL, Wolff LL, Silva JC, 2015. Trophic structure of fish fauna along the longitudinal gradient of a first-order rural stream. Acta Limnol. Bras. 27:381-393.

Nunes DM, Hartz SM, 2006. Feeding dynamics and ecomorphology of Oligosarcus jenynsii (Gunther, 1864) and Oligosarcus robustus (Menezes, 1969) in the lagoa Fortaleza, Southern Brazil. Braz. J. Biol. 66:121-132.

Oksanen J, Kindt R, Legendre P, O'Hara B, Stevens MHH, Oksanen MJ, Suggests M, 2007. The vegan package. Community Ecology Package. R package version 2.4-2. Accessed: August 2017. Available from: https:/CRAN.Rproject.org $/$ package $=$ vegan

Oliveira EF, Goulart E, Breda L, Minte-Vera CV, Ricardo L, Paiva DS, Vismara MR, 2010. Ecomorphological patterns of the fish assemblage in a tropical floodplain: effects of trophic, spatial and phylogenetic structures. Neotrop. Ichthyol. 8:569-586.

Pagotto JPA, Goulart E, Oliveira EF, Yamamura CB, 2011. Trophic ecomorphology of Siluriformes (Pisces, Osteichthyes) from a tropical stream. Braz. J. Biol. 71:469-479.

Pelicice FM, Azevedo-Santos VM, Vitule JRS, Orsi ML, Lima JrDP, Magalhães ALB, Pompeu PS, Petrere M, Agostinho AA, 2017. Neotropical freshwater fishes imperilled by unsustainable policies. Fish Fish. 18:1119-1133.

Peres-Neto PR, Bizerril CRSF, Iglesias R, 1995. An overview of some aspects of river ecology: a case study on fish assemblage distribution in an eastern Brazilian coastal river, pp. 317-334. In: F.A. Esteves (ed.), [Estrutura, funcionamento e manejo de ecossistemas brasileiros]. Série Oecologia Brasiliensis, Rio de Janeiro.

Poff NL, Allan JD, 1995. Functional organization of stream fish assemblages in relation to hydrological variability. Ecology 76:606-627.

Pouilly M, Barrera S, Rosales C, 2006. Changes of taxonomic and trophic structure of fish assemblages along an environmental gradient in the Upper Beni watershed (Bolivia). J. Fish Biol. 68:137-156.

R Core Team, 2015. R: A language and environment for statistical computing. R Foundation for Statistical Computing, Vienna, Austria. http://www.R-project.org/.

Reis RE, Kullander SO, Ferraris Jr CJ, 2003. Check list of freshwater fishes of South and Central America. Edipucrs, Porto Alegre: 742 pp.

Rodrigues FL, Bemvenuti MA, 2001. [Hábito alimentar e osteologia da boca do peixe-rei, Odontesthes humensis de Buen (Atheriniformes, Atherinopsidae) na Lagoa Mirim, Rio Grande do Sul, Brasil].[Article in POrtuguese]. Rev. Bras. Zool. 18:793-802.

Röpke CP, Amadio S, Zuanon J, Ferreira EJG, Pires THS, Winemiller KO, 2017. Simultaneous abrupt shifts in hydrology and fish assemblage structure in a floodplain lake in the central Amazon. Sci. Rep. 7:1-10.

Saint-Béat B, Baird D, Asmus H, Asmus R, Bacher C, Pacella SR, Johnson GA, David V, Vézina AF, Niquil N, 2015. Trophic networks: How do teories link ecosystem structure and functioning to stability properties? A review. Ecol. Indic. 52:458-471.

Santos NCL, Santana HS, Ortega JCG, Dias RM, Stegmann LF, Isabela Maria da Silva Araújo IMS, Severi W, Bini LM, Gomes LC, Agostinho AA, 2017. Environmental filters predict the trait composition of fish communities in reservoir cascades. Hydrobiologia 802:245-253.

Schork G, Hermes-Silva S, Zaniboni-Filho, E, 2013. Analysis of fishing activity in the Itá reservoir, Upper Uruguay River, in the period 2004-2009. Braz. J. Biol. 73:559-571.

Schork G, Zaniboni-Filho E, 2017. Structure dynamics of a fish community over ten years of formation in the reservoir of the hydroelectric power plant in upper Uruguay River. Braz. J. Biol. 77: 710-723.

Serra S, Bessonart J, Mello FT, Duarte A, Malabarba L, Loureiro M, 2014. [Peces del Río Negro].[Book in Spanish]. MGAPDINARA, Montevideo: 207 pp.

Sokal RR, Rohlf FJ, 1995. Biometry. W. H. Freeman, New York: $887 \mathrm{pp}$.

Stanford JA, Ward JV, 2001. Revisiting the serial discontinuity concept. River Res. Appl. 17:303-310.

Strassburger L, 2005. [Uso da terra nas bacias hidrográficas do rio do Peixe (SC) e do rio Pelotas (RS/SC) e sua influência na limnologia do reservatório da UHE-ITÁ (RS/SC)]. [Master's Thesis in Portuguese]. Universidade Federal de Santa Maria, Brazil.

Teixeira I, Bennemann ST, 2007. [Ecomorfologia refletindo a dieta dos peixes em um reservatório no sul do Brasil].[Article in Portuguese]. Biota Neotrop. 7:67-76.

Troia MJ, Gido KB, 2015. Functional strategies drive community assembly of stream fishes along environmental gradients and across spatial scales. Oecologia 177:545-559.

Uieda VS, Castro RMC, 1999. [Coleta e fixação de peixes de riachos]. In: E.P Caramaschi, R. Mazzoni, P.R. Bizerril and CRSF Peres-Neto (eds.), [Ecologia de peixes de riachos: estado atual e perspectivas]. Oecologia Brasiliensis, Rio de Janeiro.

Vannote RL, Minshall GW, Cummings KW, Sedell JR, Cushing CE, 1980. The River Continuum Concept. Can. J. Fish. Aquat. Sci. 37:130-137.

Ward JV, Stanford JA, 1983. The serial discontinuity concept of lotic ecosystems, p. 29-42. In: T.D. Fontaine and S.M. Bartell (eds.), Dynamics of lotic ecosystems. Ann Arbor Science Publ., Ann Arbor.

Winemiller KO, Fitzgerald DB, Bower LM, Pianka ER, 2015. Functional traits, convergent evolution, and periodic tables of niches. Ecol. Lett. 18:737-751.

Wolff LL, Carniatto N, Hahn NS, 2013. Longitudinal use of feeding resources and distribution of fish trophic guilds in a coastal Atlantic stream, southern Brazil. Neotrop. Ichthyol. 11:375-386.

Zaniboni-Filho E, Schulz U, 2003. Migratory fishes of the Uruguay River, pp. 157-194. In: J. Carolsfeld, B. Harvey, C. Ross and A. Baer (eds.), Migratory fishes of South America: biology, fisheries, and conservation status. World Fisheries Trust, IDRC, World Bank, Victoria.

Zeni JO, Casatti L, 2014. The influence of habitat homogenization on the trophic structure of fish fauna in tropical streams. Hydrobiologia 726:259-270. 